\section{Pavan Kalyan Lingampally}

Research Scholar School of Mechanical and Building Sciences Vellore Institute of Technology, Chennai, Tamil Nadu

India

Arockia Selvakumar A

Associate Professor

Design and Automation Research group School of Mechanical and Building Sciences Vellore Institute of Technology, Chennai, Tamil Nadu

\title{
Kinematic and Workspace Analysis of a Parallel Rehabilitation Device for Head- Neck Injured Patients
}

Current treatment for patients suffering from cervical spine injuries is by static braces which causes discomfort and immobilization of the neck. This paper presents a novel comfortable wearable therapy device for treating patients suffering with head/neck posture problems using parallel mechanism concept. To achieve this, a conceptual design of a threedegrees-of-freedom Revolute-Prismatic-Spherical configuration parallel manipulator with 3 extensible links is proposed. However, precision and workspace are the general considerations for designing a parallel manipulator. In this research, workspace and position analysis is carried out for the device. By applying geometrical method and vector-loop approach, the inverse kinematics equations are derived. The parallel manipulator is modeled using SOLIDWORKS and simulated using MATLAB. From the simulation results, stroke length of the actuators, angular tilt and position of the moving platform is obtained. To validate the simulation results a preliminary prototype is built and tests were carried. The obtained results found to be satisfying the cause of the research. Furthermore, the device needs to automated and safely operated under the therapist supervision.

Keywords: Parallel manipulator, Forward Kinematics, Precision, Workspace, SOLIDWORKS and MATLAB.

\section{INTRODUCTION}

Many Research groups proposed and developed a variety of humanoid neck mechanisms using different mechanisms. Based on the available neck mechanism it is understood that the neck motion can be mimicked using four types of mechanisms, they are serial, parallel, spring-based and spherical necks.

Many researchers, tried to replicate human neck design using serial structures. In general the serial necks are opted to link the head and torso of robot due to its simple, compact and easiness in control of the DC motors. The Robot-Cub (iCub) has a 3DOF serial neck [1]. The WE-4 [2] and the ROMAN [3] have a 4DOF serial neck. Coming to the parallel necks this structure is actuated by actuators which can either be controlled by DC motors or pneumatic cylinders and these are a combination of Universal, Prismatic, Revolute, and Spherical joints. However, it is difficult to reach maximum range of workspace. Spherical necks are designed using ball joints. Sabater developed a spherical neck using screw theory [4].

The parallel connection is an alternative type where the links are arranged parallel to each other to form a closed kinematic chain or structure. The idea of using

Received: August 2018, Accepted: November 2018

Correspondence to: Dr. Arockia Selvakumar A

SMBS, Vellore Institute of Technology, Chennai,

Tamil Nadu, India.

E-mail: arockia.selvakumar@vit.ac.in

doi: $10.5937 /$ fmet1903405L

(C) Faculty of Mechanical Engineering, Belgrade. All rights reserved parallel connections manipulators were initially implemented by Stewart (1965) in a research paper, which suggests using it as a base motion aircraft simulator [5]. Since 1965, the Stewart platform has been the base for building different applications in various fields of research like CAREN (Computer Assisted Rehabilitation Environment) which is used clinical analysis system for evaluation of human balance system developed by University of South Florida [6]. In industries point of view the researchers [7] applied this mechanism for machining and profile cutting operations. As the parallel manipulator are renowned for their payload capacity and capable of attaining a very smooth motion $[5,8,9]$. Hence, the use of parallel manipulators can suit the conditions to aid patient requirement without causing any discomfort.

The present scenario for treating the patients with amyotrophic lateral sclerosis (neurological disorder) is by using static braces as shown in Figure 1which helps to keep the patient head steady from dropping. However, by using static braces the head drop can be limited but the head is immobilized and restricted to a single configuration which inevitably leads to strain on muscle. Hence, there is a need to design a system for the patients, which will allow the patients to keep the head steady from free fall and to increase the mobility of the head without straining.

The nerves and ligaments around neck support the weight of head to maintain the steadiness of head. A model of the human cervical spine is shown in the Figure 2. When coming to the arrangement/construction 
of the nerves around the neck they appeared to be linearly parallel to one another where the load distribution on nerves is done equally along with the support of the cervical spine $\left(\mathrm{C}_{1}\right.$ to $\left.\mathrm{C}_{7}\right)$. Among the seven vertebrae the first vertebrae, the atlas $\left(\mathrm{C}_{1}\right)$ holds/supports the head and axis vertebrae $\left(\mathrm{C}_{2}\right)$ which helps the head to move.

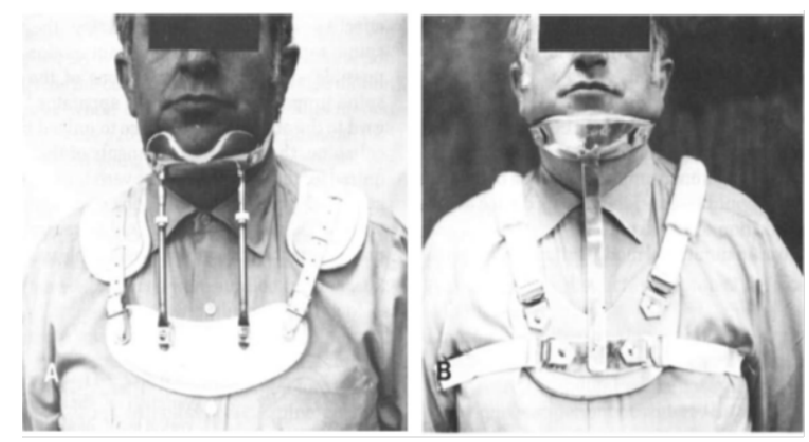

Figure 1: (A) The Four-poster cervical brace,

(B) The Guilford, Duke or long cervical brace [3]

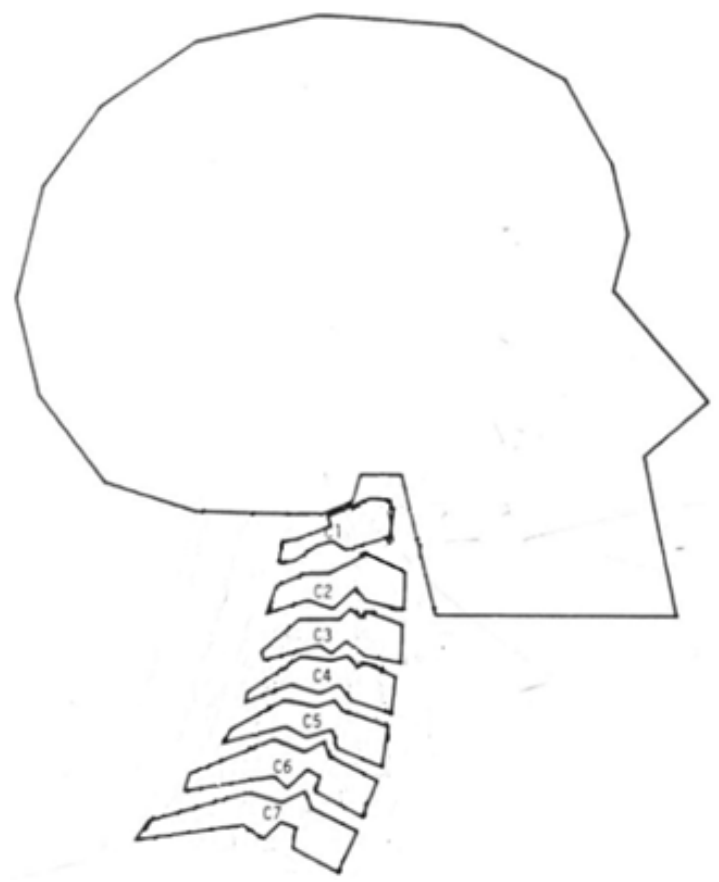

Figure 2: A Realistic Model of the Human Cervical Spine [6]

The joints between the $\mathrm{C}_{1}$ and $\mathrm{C}_{2}$ helps in neck most of rotation. The overall neck DOF is considered as 6DOF [10]. The possible motions of the cervical spine are listed in Table 1.

Table 1: Motions of the Human Neck

\begin{tabular}{|c|c|c|}
\hline \multicolumn{3}{|c|}{ Rotations of the Neck } \\
\hline $\begin{array}{c}\text { Flexion/ } \\
\text { Extension }\end{array}$ & $\begin{array}{c}\text { Forward and } \\
\text { Backward bending }\end{array}$ & $\begin{array}{c}\text { Rotation around the } \\
\text { X-axis }\end{array}$ \\
\hline $\begin{array}{c}\text { Axial } \\
\text { Rotation }\end{array}$ & Twisting & $\begin{array}{c}\text { Rotation around the } \\
\text { Y-axis }\end{array}$ \\
\hline $\begin{array}{c}\text { Lateral } \\
\text { Bending }\end{array}$ & Side bending & $\begin{array}{c}\text { Rotation around the } \\
\text { Z-axis }\end{array}$ \\
\hline
\end{tabular}

Based on the literature survey conducted, it is found that the human neck reachable work volume is small and load/volume ratio is not very high. As the parallel platforms, are suitable for applications where the workspace is small and for carrying high loads. Hence, the idea of using parallel connection is opted. The reason for reducing to 3 -DOF in this device, is because the axial rotation around the y-axis cannot be achieved due to the physical constraints of the device and also to minimize the operation complications while operating.

In past few years, various researchers [11-17] attempted in designing a humanoid neck which is moves like human neck using different approaches with a limited degrees of freedom based on the application. However, this survey addresses the information of different designs in recent trends how to design and develop a robotic neck for the application that can respond as quick as possible as a human neck.

The paper is organized as: The conceptual design of 3RPS assistive medical device was developed using SolidWorks in Section II. Section III details the forward kinematics of the platform. In Section IV Workspace analysis is detailed by using MATLAB. Section V details the obtained simulation results and provides the information regarding the reachable workspace of the device and allowable range of motion of the device it can be operated. Section VI presents the experimental study conducted based on the inference made from the simulation results. Finally, this paper concludes with a discussion of future research work explained in Section VII.

\section{CONCEPTUAL DESIGN OF REHABILITATION DEVICE}

The architecture of a 3-RPS parallel manipulator is shown in Figure. 3 which consist of a movable platform (top) and a base (fixed) platform and three identically structured supporting limbs or links. Table 2 presents the geometrical parameters of the standard human neck and the design is developed based on the dimensions. Each link joins the top and fixed platform by a Revolute joint $(\mathrm{R})$, Prismatic joint $(\mathrm{P})$, Spherical joint $(\mathrm{S})$ in a sequential order, where the prismatic joint is actuated by an electric linear actuator $[8,9]$.

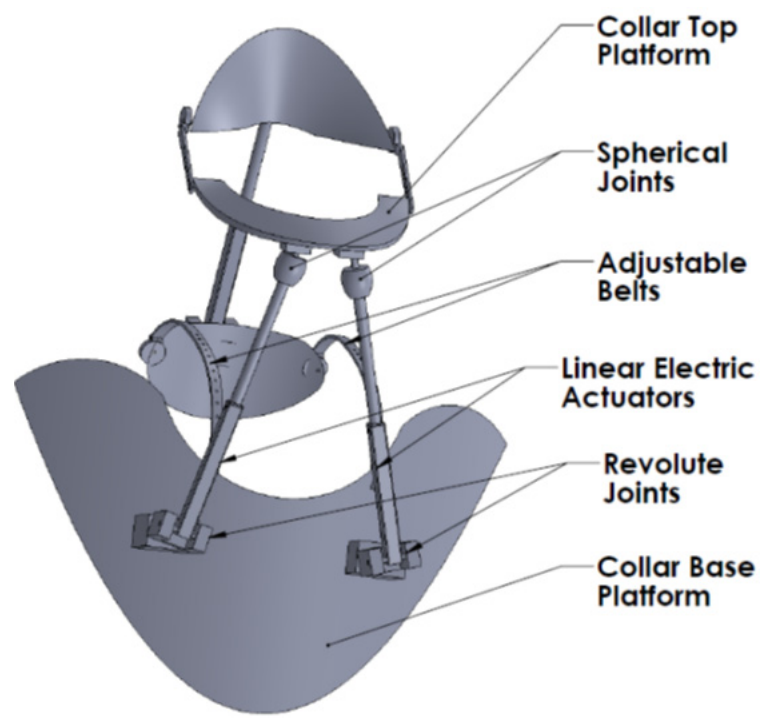

Figure 3: 3-RPS Rehabilitation Device.

The design idea of the device is to provide controlled movement of the human head by supporting the neck using parallel mechanism. To fulfill this objective, the brace is made with a platform to rest the chin and 
the platform is attached with adjustable metallic straps to fit and hold the head and on the base platform it is supported with three actuators which are equally aligned with each other. The linear actuator has a revolute joint at the base and a spherical (or) a ball joint at the top.

Table 2: Dimensions of Human Neck (mm) [18]

\begin{tabular}{|c|c|}
\hline \multirow{2}{*}{ Circumference } & Regular (330- 410) \\
\cline { 2 - 2 } & Large (410-480) \\
\hline \multirow{2}{*}{ Height } & Regular (80) \\
\cline { 2 - 2 } & Large (120) \\
\hline
\end{tabular}

\section{POSITION ANALYSIS OF 3-DOF PARALLEL MANIPULATOR}

A base coordinate system $\{R\}$ is placed at the base centre $O$ with its $\mathrm{Z}$-axis perpendicular to the base platform. Likewise, the coordinate system $\{r\}$ is located at the center of the top movable platform. The joints pairs attached to the top and base are denoted by $S_{1}, S_{2}$, $S_{3}$ and $R_{1}, R_{2}, R_{3}$ respectively.

The coordinates of $\mathrm{R}_{i}, i=1,2,3$, with respect to $\{A\}$ are denoted as $R_{i}$, and those of $r_{i}$ with respect to $\{B\}$.

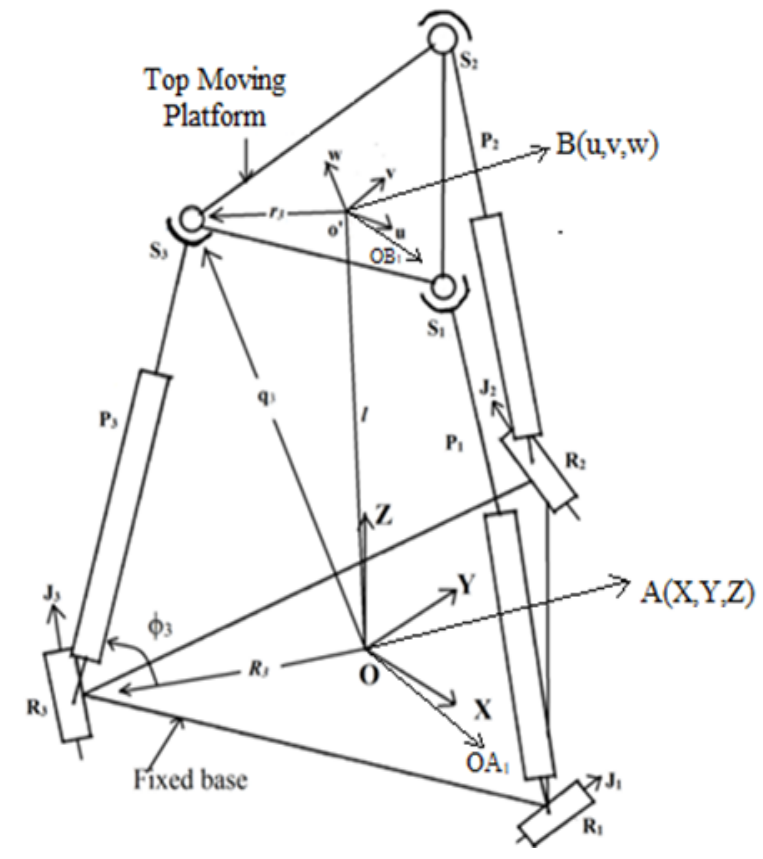

Figure 4: Schematic representation of Spatial 3-RPS [2].

In general workspace of the parallel manipulator is affected by 3 types of constraints. They are: Link length limitations, Joint angle limitation and Link interference.

Three actuators connect the moving platform at points $\mathrm{B}_{\mathrm{i}}$ by spherical joints to the fixed base at points $\mathrm{A}_{\mathrm{i}}$ by revolute joints. Each limb consists of an upper and lower member connected by a prismatic joint. These three prismatic joints are used as the inputs to the manipulator.

\subsection{Mobility Equation}

Obtaining DOF for Parallel Manipulators is dependent on the number of links attached to the moving platform and the base platform. In this mechanism Overall, there are eight links and 9 joints out of which only three pris- matic joints are actuated, three revolute joints and three multi-degree-of-freedom spherical joints which are passive. Here the top moving platform is the output link. Hence, the degrees of freedom of the mechanism are:

$$
\begin{aligned}
& F=\lambda(n-j-1)+\sum_{i} f_{i} \\
& F=6(8-9-1)+(3+3+9)=3
\end{aligned}
$$

\subsection{Geometry of the Manipulator}

For the purpose of analysis, $\mathrm{A}(\mathrm{x}, \mathrm{y}, \mathrm{z})$ and $\mathrm{B}(\mathrm{u}, \mathrm{v}, \mathrm{w})$ are considered to be the two Cartesian coordinate systems attached to the fixed base and moving platform respectively. The following assumptions are made. Points $A_{1}, A_{2}, A_{3}$ lie on the $x-y$ plane and $B_{1}, B_{2}, B_{3}$ lie on the $\mathrm{u}-\mathrm{v}$ plane. The origin $\mathrm{O}$ of the fixed coordinate system is located at the centroid of $\triangle \mathrm{A}_{1} \mathrm{~A}_{2} \mathrm{~A}_{3}$ and the $\mathrm{x}$ axis points in the direction of $\overline{O A}_{1}$ as shown in Figure.4.

The transformation from the top platform to the base platform can be written by a $3 \times 3$ rotation matrix ${ }^{A} R_{B}$ defined by three Euler angles. Assuming that the top platform initial position always coincides with the base platform. Let $\mathrm{u}, \mathrm{v}$ and $\mathrm{w}$ be the three unit vectors defined along the axes of the moving coordinate system $\mathrm{B}$, then the rotation matrix can be expressed in terms of the direction cosines of $\mathrm{u}, \mathrm{v}$ and $\mathrm{w}$ is given below

$$
\begin{aligned}
& { }^{A} R_{B}=\left[\begin{array}{lll}
u_{x} & v_{x} & w_{x} \\
u_{y} & v_{y} & w_{y} \\
u_{z} & v_{z} & w_{z}
\end{array}\right] \\
& { }^{A} R_{B}=R_{y}(\beta) R_{x}(\alpha) R_{z}(\gamma)= \\
& =\left[\begin{array}{ccc}
c \beta c \gamma+s \alpha s \beta s \gamma & -c \beta s \gamma+s \alpha s \beta c \gamma & c \alpha s \beta \\
c \alpha s \gamma & c \alpha c \gamma & -s \alpha \\
-s \beta c \gamma+s \alpha c \beta s \gamma & s \beta s \gamma+s \alpha c \beta c \gamma & c \alpha c \beta
\end{array}\right] \\
& R_{1}=[g, 0,0]^{T}, R_{2}=\left[-\frac{1}{2} g, \frac{\sqrt{3}}{2} g, 0\right]^{T} \\
& R_{3}=\left[-\frac{1}{2} g,-\frac{\sqrt{3}}{2} g, 0\right]^{T} \\
& { }_{r_{1}}=[h, 0,0]^{T}, r_{2}=\left[-\frac{1}{2} h, \frac{\sqrt{3}}{2} h, 0\right]^{T} \\
& B_{r_{3}}=\left[-\frac{1}{2} h,-\frac{\sqrt{3}}{2} h, 0\right]^{T}
\end{aligned}
$$

where

$\mathrm{g}$ - Distance from the centre of the base platform to the revolute joints.

$\mathrm{h}$ - Distance from the centre of the moving platform to the spherical joints.

$$
\begin{aligned}
& { }^{A} \mathbf{r}_{\mathbf{B} i} \text { (or) } \mathbf{q}_{\mathbf{i}}=l+{ }^{A} \mathbf{r}_{\mathbf{B} i}{ }^{A} R_{\mathbf{B}}{ }^{\mathbf{B}} \mathbf{r}_{\mathbf{i}} \\
& { }^{A} \mathbf{r}_{\mathbf{B} 1}=\left[\begin{array}{l}
l_{x}+h u_{x} \\
l_{y}+h u_{y} \\
l_{z}+h u_{z}
\end{array}\right]
\end{aligned}
$$




$$
\begin{gathered}
{ }^{A} \mathbf{r}_{\mathbf{B} 2}=\left[\begin{array}{l}
l_{x}-\frac{1}{2} h u_{x}+\frac{\sqrt{3}}{2} h v_{x} \\
l_{y}-\frac{1}{2} h u_{y}+\frac{\sqrt{3}}{2} h v_{y} \\
l_{z}-\frac{1}{2} h u_{z}+\frac{\sqrt{3}}{2} h v_{z}
\end{array}\right] \\
{ }^{A} \mathbf{r}_{\mathbf{B} 2}=\left[\begin{array}{l}
l_{x}-\frac{1}{2} h u_{x}-\frac{\sqrt{3}}{2} h v_{x} \\
l_{y}-\frac{1}{2} h u_{y}-\frac{\sqrt{3}}{2} h v_{y} \\
l_{z}-\frac{1}{2} h u_{z}-\frac{\sqrt{3}}{2} h v_{z}
\end{array}\right]
\end{gathered}
$$

The length of a $\operatorname{limb} P_{i}$ from the figure 5 is given by:

$$
R_{i}^{2}=\left[R_{i}-r_{i}\right]^{T}\left[R_{i}-r_{i}\right]
$$

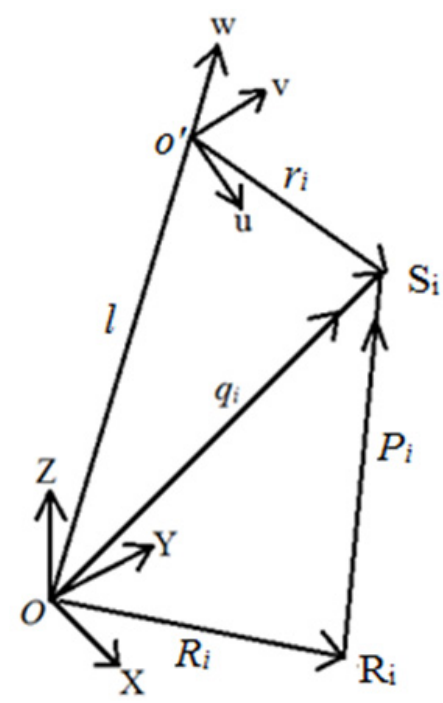

Figure 5: Single leg movement of 3-RPS Mechanism [2].

By substituting equation (1) coordinate points and the equations $7,8,9$ into equation 10 which results in finding the leg lengths of the manipulator.

$$
\begin{aligned}
& P_{1}^{2}=l_{x}^{2}+l_{y}^{2}+l_{z}^{2}+2 h\left(l_{x} u_{x}+l_{y} u_{y}+l_{z} u_{z}\right)- \\
& -2 g l_{x}-2 g h u_{x}+g^{2}+g h^{2} \\
& P_{2}^{2}=l_{x}^{2}+l_{y}^{2}+l_{z}^{2}+g^{2}+h^{2}-h\left(l_{x} u_{x}+l_{y} u_{y}+l_{z} u_{z}\right)+ \\
& +\sqrt{3} h\left(l_{x} v_{x}+l_{y} v_{y}+l v_{z}\right)+g\left(l_{x}+\sqrt{3} l_{y}\right)- \\
& \frac{1}{2} g h\left(u_{x}-\sqrt{3} u_{y}\right)+\frac{1}{2} g h\left(\sqrt{3} v_{x}-3 v_{y}\right) \\
& P_{3}^{2}=l_{x}^{2}+l_{y}^{2}+l_{z}^{2}+g^{2}+h^{2}-h\left(l_{x} u_{x}+l_{y} u_{y}+l_{z} u_{z}\right)- \\
& +\sqrt{3} h\left(l_{x} v_{x}+l_{y} v_{y}+l v_{z}\right)+g\left(l_{x}+\sqrt{3} l_{y}\right)- \\
& \frac{1}{2} g h\left(u_{x}+\sqrt{3} u_{y}\right)-\frac{1}{2} g h\left(\sqrt{3} v_{x}-3 v_{y}\right)
\end{aligned}
$$

Hence, by determining the angle of the moving platform, the actuators displacement can be determined. By providing the known rotational angles, workspace of the platform can be determined.

\section{WORKSPACE ANALYSIS}

For the current study, the design parameters of the moving and fixed platform were varied. It is wide known that the reachable workspace of the parallel manipulators is smaller when compared to the serial. In parallel manipulators workspace affects the design, position of the manipulator and dexterity to perform the task. So, analyzing the workspace shape and volume is important for improving the precision of parallel manipulators.

Simulation studies were conducted for the model to check the position of the designed platform and also to determine the safe workspace area.

The mechanical design is done using the CAD software SolidWorks and the design is imported into Sim-Mechanics. SimMechanics is used to simulate the dynamic movement of the platform either in real or graphic environment. The SimMechanics model considers the geometric and joint constraints without omitting. Friction is ignored in this model. As the model consists of many number of rigid bodies the Simulink blocks connects the joints of system based on the motion. The SimMechanics model requires inertial properties such as DOF and constraints, along with the assembled coordinate systems of the structure to build a model. These properties were automatically determined when the model is imported into MATLAB/Simulink environment. This process is simplified by using the SolidWorks modeling software.

The workspace of the proposed model is limited due to the human neck constraints and the reachable distance of the drives and the joints.

The simulation studies were conducted for three different neck sizes considered to be small, average and large. Based on the conducted study, dimensions mentioned in Table 3 were considered to be the average dimensions of a human neck for the current study. In order to visualize the workspace of the humanoid neck mechanism device a code was executed in Matlab for the workspace analysis. The program inputs include the connection points of the fixed and moving platform, the radius of these connections on both platforms, the given orientation of the moving platform. The code is written in such a way that the bottom platform is fixed and the moving top platform is maintained at a distance which is the average height of the human neck. The coordinate points are equidistant from each other. The actuators which are shown in figure.2 CAD model are visualized as the connecting lines between the top and bottom plate. The program is coded to operate the model with the orientation angle between $+/-15^{0}$ to $0^{0}$ and the translation angle between $+/-15^{0}$ to $0^{0}$ with a maximum incremental angle of $5^{0}$ in both directions and the simulation results are shown below.

\subsection{Case Study}

In this study forward kinematic analysis of the proposed 3-rps parallel mechanism is presented to demonstrate the effective positioning the proposed model. The dimensions of the top and base platform and coordinate reference frames are assigned in below table 2 for the position analysis. 
Table 3. Coordinate reference frames (top \& base platforms)

\begin{tabular}{|c|c|c|}
\hline $\begin{array}{c}\text { Top } \\
(\mathrm{r} \text { in } \mathrm{mm})\end{array}$ & $\begin{array}{c}\text { Base } \\
(\mathrm{R} \text { in } \mathrm{mm})\end{array}$ & $\begin{array}{c}(\mathrm{X}, \mathrm{Y}, \mathrm{Z})^{T} \\
(\mathrm{~mm})\end{array}$ \\
\hline 250 & 320 & $(207,131,100)$ \\
\hline
\end{tabular}

The position of the each link can be obtained as shown in table 4 . And the following simulation depicts the configuration of the model.

Table 4. Position of the Top Moving platform

\begin{tabular}{|c|c|c|c|}
\hline S.No. & $\begin{array}{c}\beta \\
\text { (degrees) }\end{array}$ & $\begin{array}{c}\gamma \\
\text { (degrees) }\end{array}$ & $\begin{array}{c}\left(P_{1} P_{2} P_{3}\right) \\
(\mathrm{mm})\end{array}$ \\
\hline (a) & $-15^{0}$ & $-15^{0}$ & $(162.5,12.7,124.78)$ \\
\hline (b) & $-15^{0}$ & $-10^{0}$ & $(141.9,23,135)$ \\
\hline (c) & $-15^{0}$ & $-5^{0}$ & $(121,33.5,145.5)$ \\
\hline (d) & $-15^{0}$ & $0^{0}$ & $(100,44,156)$ \\
\hline (e) & $-15^{0}$ & $5^{0}$ & $(79,54.5,166.5)$ \\
\hline (f) & $-15^{0}$ & $10^{\circ}$ & $(58,65,177)$ \\
\hline (g) & $-15^{0}$ & $15^{0}$ & $(37.5,75,187)$ \\
\hline (h) & $-10^{0}$ & $-15^{0}$ & $(163.7,30.5,105.7)$ \\
\hline (i) & $-10^{0}$ & $-10^{0}$ & $(142.75,41,116)$ \\
\hline (j) & $-10^{0}$ & $-5^{0}$ & $(121.5,51.7,126.9)$ \\
\hline (k) & $-10^{\circ}$ & $0^{0}$ & $(100,62,137.5)$ \\
\hline (1) & $-10^{0}$ & $5^{0}$ & $(78.5,73,148.3)$ \\
\hline (m) & $-10^{0}$ & $10^{0}$ & $(57,83.7,159)$ \\
\hline (n) & $-10^{0}$ & $15^{0}$ & $(36,94,169.5)$ \\
\hline (o) & $-5^{0}$ & $-15^{0}$ & $(164.45,49,86.6)$ \\
\hline (p) & $-5^{0}$ & $-10^{0}$ & $(143.2,59.5,97.2)$ \\
\hline (q) & $-5^{0}$ & $-5^{0}$ & $(121.7,70.2,108)$ \\
\hline$(\mathrm{r})$ & $-5^{0}$ & $0^{0}$ & $(100,81,119)$ \\
\hline (s) & $-5^{0}$ & $5^{0}$ & $(78.3,92,130)$ \\
\hline$(\mathrm{t})$ & $-5^{0}$ & $10^{0}$ & $(56.7,102.7,140.5)$ \\
\hline (u) & $-5^{0}$ & $15^{0}$ & $(35.5,113.5,151)$ \\
\hline (v) & $0^{0}$ & $-15^{0}$ & $(164.7,67.8,67.8)$ \\
\hline (w) & $0^{0}$ & $-10^{0}$ & $(143.5,78,78)$ \\
\hline (x) & $0^{0}$ & $-5^{0}$ & $(121.7,89,89)$ \\
\hline (y) & $0^{0}$ & $10^{0}$ & $(56.5,121.7,121.7)$ \\
\hline (z) & $0^{0}$ & $15^{0}$ & $(35.3,132.5,132.5)$ \\
\hline
\end{tabular}

\section{EXPERIMENTAL PROCEDURE}

An Experimental prototype is built by considering the geometrical parameters of the human head/neck as shown in Figure 6 dimensional parameters mentioned in Table 3 which are considered to be the dimensions of average human neck.

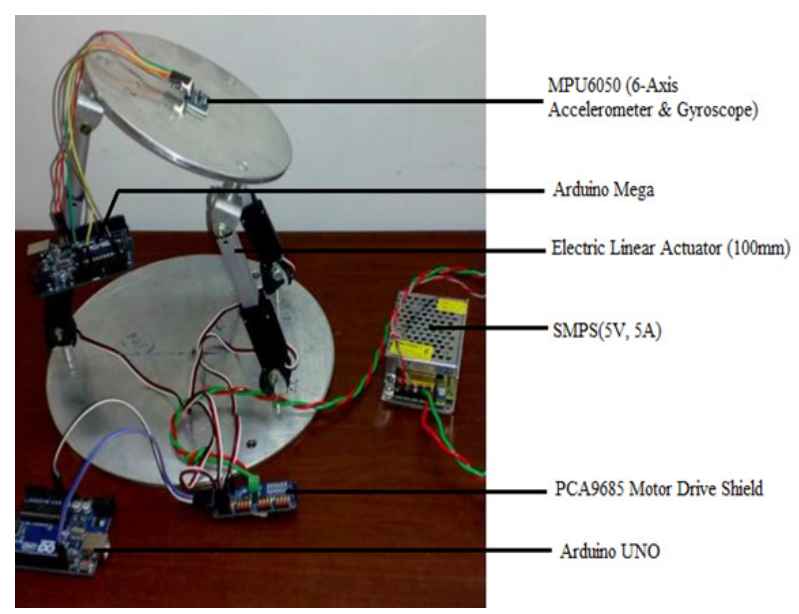

Figure 6: Experimental Prototype with Control system

The actuators are arranged accor-ding to the obtained simulation results. From the simu-lation results it is found that the maximum extension of the links ranges from $120 \mathrm{~mm}$ to $160 \mathrm{~mm}$ for maximum angular tilt of $15^{\circ}$. Figure 7 displays the actual fabricated cervical collar with parallel actuator assembly according to design shown in Figure 3.

Based on the simulation results the actuators stroke length is finalized for the prototype.

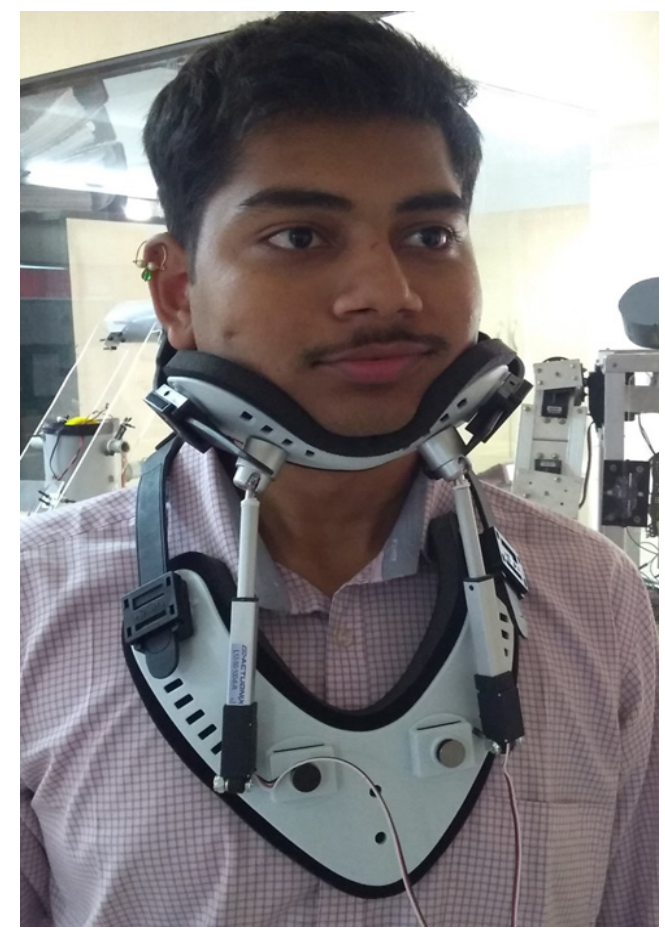

Figure 7: Prototype of the Parallel Mechanism based Cervical Collar.

\subsection{Control System}

Figure 8 presents the control system for the parallel mechanism. An inverse kinematic code is written and complied in Arduino and the code is imported into the Arduino UNO controller using a computer. The controller is connected to a servo shield and the servo shield is powered with a $5 \mathrm{~V}, 5 \mathrm{~A}$ SMPS to supply a constant current to the electric linear atuators. The top end of the actuators are connected to the moving plate, where the top moving platform is attached with a gyroscope to obtain the angular tilt of the moving platform.

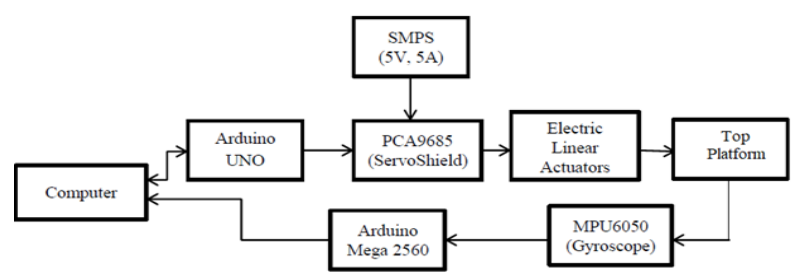

Figure 8: Block diagram of the Control system

\section{RESULTS AND DISCUSSION}

Forward kinematics is applied to the 3-RPS manipulator, by using Matlab/Simulink the workspace volume of the moving platform and for different orientation angles were determined. As the simulations illustrated that the model can be operated safely without 
any interference with the mechanism between $-15^{0}$ to $15^{0}$ of angle which is shown in figure 9 (a)-(b). This simulation study was conducted to find the link lengths by varying the moving platform angles which are listed in the table 3. Based on the, simulation results it is found that the rotation motions are possible along the $\mathrm{x}$ and z-axes not along the y-axis.

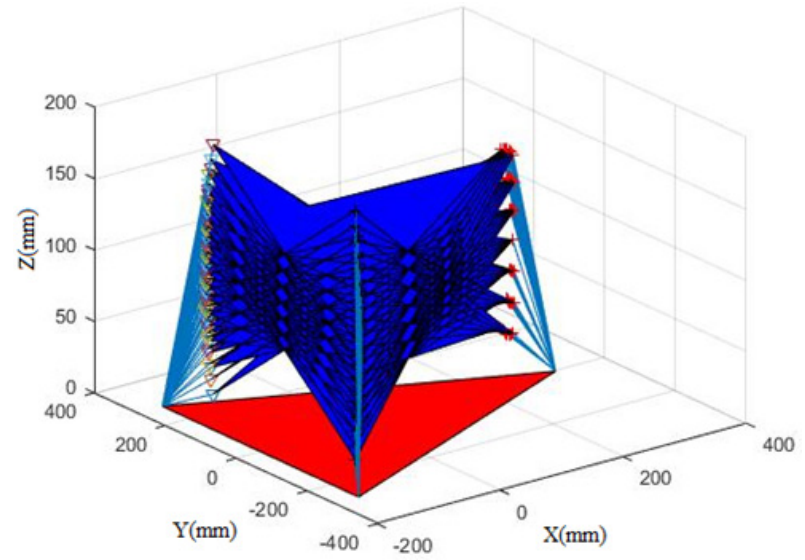

a) Displacement of the link lengths.

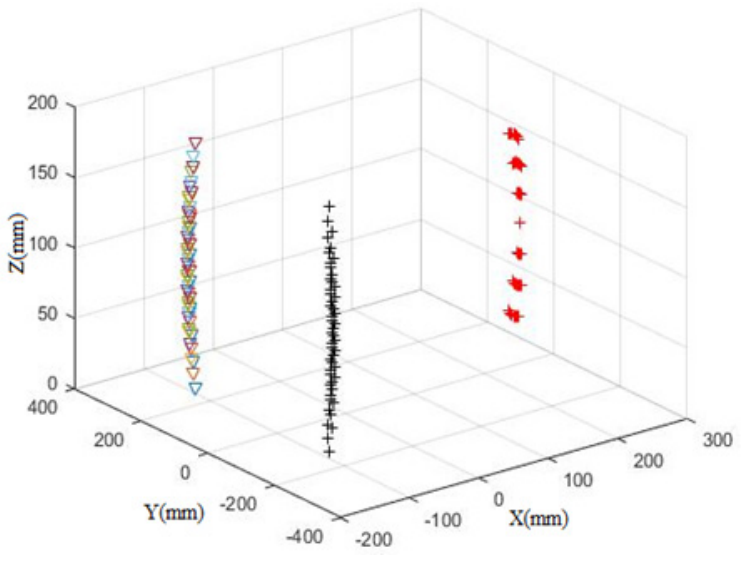

b) Workspace of the 3-RPS Neck Platform.

Figure 9: (a) - (b) Simulation Graphs of Moving Platform.

\section{CONCLUSION}

This paper addresses a conceptual design of the 3-rps humanoid parallel neck manipulator and also found workspace of the designed model. Based on the study conducted following conclusions are made:

1. A special purpose assistive device to aid people suffering in head and neck motion is proposed.

2. Matlab based simulations were conducted to verify the feasibility and performance of the model.

3. Minimum and maximum extension and retraction of the links were found and based on which the stroke length of the actuators can be decided.

4. Range of angular tilt of the top moving platform is obtained based on the provided input parameters. In the future research, a realistic exoskeleton system will be prototyped with the proposed control system.

\section{ACKNOWLEDGMENT}

This work is self-financed and a patent has been filed and the details as follows: Title of the invention: An
Orthopedic Wearable Device for Treating Patients with Cervical Spine Injuries.

Application No: 201841014653. The Patent office, Chennai, India, Journal No. 16/2018, dated: 20/04/2018.

\section{REFERENCES}

[1] Beira, R., Lopes, M. Praca, M., Santos-Victor, J., Bernardino, A., Metta, G., Becchi, F. and Saltaren, R.: Design of the robot-cub (iCub) head. Proceedings of the IEEE International Conference on Robotics and Automation. Orlando, USA, 94100, 2006.

[2] Zecca, M., Roccella, S., Carrozza, M.C., Miwa, H., Itoh, K., Cappiello, G., Cabibihan, J.J., Matsumoto, M., Takanobu, H., Dario, P. and Takanishi, A.: On the development of the emotion expression humanoid robot WE-4RII with RCH1. Proceedings of the Fourth IEEE/RAS International Conference on Humanoid Robots. 1, 235-252, 2004.

[3] Hirth, J., Schmitz, N. and Berns, K.: Emotional Architecture for the Humanoid Robot Head ROMAN. Proceedings of the IEEE International Conference on Robotics and Automation, Roma, 2150-2155, 2007.

[4] Sabater, J.M., Garcia, N., Perez, C., Azorin, J. M., Saltaren, R.J. and Yime, E.: Design and analysis of a spherical humanoid neck using screw theory. Proceedings of the First IEEE/RAS-EMBS International Conference on Biomedical Robotics and Biomechatronics, Pisa, 1166-1171, 2006.

[5] Stewart, D.: A platform with six degrees of freedom. Proceedings of the Institution of Mechanical Engineers, 180(1), 371-378, 1965.

[6] Isaacson, B.M., Swanson, T.M. and Pasquina, P.F.: The use of a computer-assisted rehabilitation environment (CAREN) for enhancing wounded warrior rehabilitation regimens. The Journal of Spinal Cord Medicine. 36(4), 296-299, 2013

[7] Ruiz, A., Campa, F.J., Roldán-Paraponiaris, C., Altuzarra, O., Pinto, C.: Experimental validation of the kinematic design of 3-PRS compliant parallel mechanisms, Journal of Mechatronics, 39, 77-88, 2016.

[8] Lung-Wen, Tsai.: Robot Analysis and Design: The Mechanics of Serial and Parallel Manipulators $\left(1^{\text {st }}\right.$ ed.). New York: John Wiley \& Sons, Inc. 1999.

[9] Fichter, E.F.: A Stewart Platform- Based Manipulator: General Theory and Practical Construction. The International Journal of Robotics Research, 5(2), 157-182, 1986.

[10]White, A.A., Panjabi, M.M.: Clinical Biomechanics of the Spine (2nd edition) Baltimore: Lippincott Williams \& Wilkins, 1999.

[11] Pavan Kalyan, Lingampally and Arockia Selva kumar, A.: A humanoid neck using parallel manipulators. Proceedings of the International Conference on Robotics and Automation for Humanitarian Applications (RAHA), 1-6, 2016. 
[12] Haohan, Zhang. and Sunil, K Agrawal.: An Active Neck Brace Controlled by a Joystick to Assist Head Motion. Robotics and Automation Letters IEEE, 3, 37-43, 2018.

[13] Wu, D., Wang, L. and Li, P.: A 6-DOF exoskeleton for head and neck motion assist with parallel manipulator and sEMG based control. Proceedings of the International Conference on Control, Decision and Information Technologies. St. Julian's. 341-344, 2016.

[14] Park, J. H., Zanotto, D., Vashista, V., Jin, X., Stegall, P. and Agrawal, S. K.: Second Spine: A device to relieve stresses on the upper body during loaded walking. Proceedings of the fifth IEEE RAS/EMBS International Conference on Biomedical Robotics and Biomechatronics, Sao Paulo, 689-694, 2014.

[15] Park, J., Stegall, P., Zanotto, D., Vashista, V., Jin, X., Agrawal, S.K.: Design of the Second Spine: A Secondary Pathway to Transfer Loads From the Shoulders to the Pelvis. Proceedings of the Thirty seventh Mechanisms and Robotics Conference ASME. International Design Engineering Technical Conferences and Computers and Information in Engineering Conference, 6(B), 2015.

[16] Agrawal, S.K., Desmier, G. and Li, S.: Fabrication and Analysis of a Novel 3 DOF Parallel Wrist Mechanism. ASME. Journal of Mechanical Design, 117(2A), 343-345, 1995.

[17] Yonas, Tadesse., Kamesh, Subbarao, Shashank, Priya.: Realizing a Humanoid Neck with Serial Chain Four-bar Mechanism. Journal of Intelligent Material Systems and Structures, 21(12), 1169 1191, 2010.
[18] Braceability - Philadelphia: Retrieved March 14, 2018, from https://www.braceability.com/philadel phia-hard-cervical-collar.

\section{КИНЕМАТИЧКА И АНАЛИЗА РАДНОГ \\ ПРОСТОРА ПАРАЛЕЛНОГ УРЕБАЈА ЗА РЕХАБИЛИТАЦИЈУ ПАЦИЈЕНАТА СА ПОВРЕДОМ ВРАТНЕ КИЧМЕ}

\section{П.К. Лингампали, А. Селвакумар А}

Данас се терапија пацијената са повредом вратне кичме спроводи помоћу фиксне протезе која изазива нелагодност и имобилизацију врата. Рад приказује нови удобан уређај за терапију пацијената који имају проблема са положајем главе и врата, а који се базира на концепцији паралелног механизма. Предложено је идејно решење паралелног манипулатора са 3 екстензибилне везе који има 3 степена слободе и ротирајућу призматичну сферну конфигурацију. Прецизност и радни простор су најважнији у дизајнирању паралелног манипулатора. У раду се анализира радни простор и положај код коришћења уређаја. Геометријском и методом векторске петље изведене су једначине инверзне кинематике. Паралелни манипулатор је моделиран помоћу SOLIDWORKS и MATLAB софтвера. Симулацијом су добијени дужина удара актуатора, нагиб угла и положај покретне платформе. У циљу евалуације резултата симулације израђен је прелиминарни прототип и извршена су испитивања. Добијени резултати задовољавају циљ истраживања. Потребно је да се изврши аутоматизација уређаја и безбедан рад под надзором терапеута. 